\title{
Die homiletiek van Karl Barth
}

\author{
TFJ Dreyer
}

\begin{abstract}
Karl Barth's homiletical views

Karl Barth is well-known for his theology and dogmatics. His struggle as a young preacher to proclaim the word of God, inspired his theological views, especially his homiletics. This paper is an attempt to pay tribute to his homiletical views. In order to do this research it is necessary to evaluate his works against the background of the theological trends of his time. The conclusions of this paper are formed by putting Barth's homiletical principles to the test, comparing them ":ith abstracts from his sermons.
\end{abstract}

Om jou hand op papier te waag in ' $n$ poging om 'n teologiese oeuvre soos Karl Barth te evalueer is ' $n$ riskante onderneming wat 'n mens met groot huiwering aanpak. Die waagmoed tot hierdie onderneming word geïnspireer deur die ontsaglike bron van teologiese denke en besinning waaruit geput en met groot vrug benut kan word ook vir die homiletiek van ons dag.

Dit word vry algemeen aanvaar en gestel dat Barth se teologie gebore is uit die nood van die prediking. Pieterse (1979: 16) beskryf iets van die worsteling wat Barth as jong dominee beleef het, onder die geweldige pretensie dat hy op die kansel klim om die Woord van God te verkondig, en juis dit kan hy nie! 'Só worstel hy met hierdie vraag dat 'n mens tereg kan sê dat sy teologie uit die nood van die prediking gebore is.' Berkouwer (1954: 15) sê ook dat sy teologie geïnspireer is deur sy worsteling met die prediking, daarom wou hy vanuit die aksent van die triomf van die genade ' $n$ diens bewys aan die kerk en sy prediking. Vanuit hierdie stelling is dit dus geregverdig om Karl Barth se denke te ontleed soos dit uitkristalliseer in sy homiletiek. Vir die doel van hierdie studie sal daarom gefokus word op sy homiletiek.

'n Besinning oor die homiletiek kan egter bloot 'n stuk teologiese gimnastiek wees as dit nie uitmond in die praktyk van die prediking nie. Om sy homiletiese denke in die praktyk te toets, sal ons ook na enkele van sy preke kyk om te probeer bepaal in hoeverre sy prediking korreleer met sy homiletiese teorie. 
Karl Barth is ook mens van sy tyd, daarom kan sy teologiese denke nie verstaan word los van die milieu waarin hy hom bevind het nie. Voordat ons dus sy homiletiek in die fokus kan plaas, is dit nodig om eers kursories enkele kontoere van die teologie van sy tyd aan te dui.

\section{TEOLOGIESE MILIEU}

Die teologie waarin Barth (1886-1968) geskool was, word verskillende getipeer. Dit was die periode van die hoogbloei van die neo-protestantisme wat in die liberale teologie van die laaste helfte van die 19 de en vroeg 20ste eeu sy toppunt bereik het. Dit is juis hierdie teologiese rigting waarin Barth opgelei is en waarvan hy hom wou distansieer (Berkouwer 1937: 190). Kotzé (1963: 112) reduseer die denke van sy tyd onder die noemer immanentistiese denke, waarmee die idealistiese beslotenheid van die religieuse mens binne die beperkte grense van sy eie gevoels- en gedagtelewe aangedui word. Die mens en sy vermoëns is die maatstaf van alle dinge. Die teologie van hierdie tyd word ook omskryf met die term subjektief-antropologies, omdat die mens as subjek sentraal staan (Van Niftrik 1949: 22). Van Niekerk (1984: 410-424) som die teologiese worsteling van Barth op as 'n stryd tussen die analogia fidei en analogia entis, as die sleutel tot die moontlikheid van ons spreke oor God. Barth (1970: 39) self tipeer die 19de-eeuse teologie as religionisties, omdat daar uitgegaan word van 'n algemene openbaring waarin aanvaar word dat die mens a priori religieus is.

Teen herdie agtergrond moet ons Barth se reaksiedenke verstaan. Hyself het sy teologie bestempel as 'n dubbele protes:

... enersyds teen die Piëtisme, die Rasionalistiese-Modernisme ... en andersyds teen die Rooms-Katolisisme. Maar dan vind hy in beide tog ' $n$ merkwaardige saaklike eenheid wat daarin bestaan dat beide aan die mens - Schleiermacher aan die vroom, en die Katolisisme aan die heilige en onbevlekte mens - 'n plek toeken wat aan God alleen toekom en derhalwe die vryheid en die aktualiteit van die Woord van God laat verlore gaan. En dan sien hy die teenstelling saaklik geleë in die alternatief tussen die volstrekte alleenheerskappy van die religieuse mens, of die volstrekste alleenheerskappy van God en sy Woord (Kotzé 1963: 113).

Spesifiek ten opsigte van die prediking onderskei Pieterse (1979: 17-18) die volgende aspekte wat problematies was en waarmee Barth gekonfronteer was: 
- Die oorheersende rol van die historiese kritiek wat verreikende gevolge gehad het vir die Skrifgesag en die verkondiging. Daar het 'n dualisme ontstaan tussen historiese en teologiese eksegese, tussen wetenskaplike teologie en kerklike verkondiging. Barth kom in opstand teen die feit dat hierdie metode slegs die aanvoorwerk doen, maar nie kom by die verstaan en interpretasie van die Skrif nie.

- Die diskrepansie tussen teologie en verkondiging in hierdie tyd vind sy verdigting in die explicatio-applicatio-skema. Dit kom neer op 'n spanning tussen uitleg en toepassing. Die eksegese was nie op die verkondiging gerig nie, maar het slegs gefokus op dit wat eg of oneg was in die Skrifteks. Dit het aanleiding gegee tot ' $n$ homiletiese applicatio wat los van die eksegese funksioneer.

- Die teologie van die neo-protestantisme het die boodskap van die prediking gerelativeer en geëlimineer.

Die teologiese problematiek in die tyd van Barth was in sy diepste wese die vraag na die verstaan van die Skrif, dus 'n hermeneutiese vraagstuk. Hierop het Barth ten dienste van die verkondiging van die kerk, 'n antwoord probeer gee.

\section{GRONDLYNE IN DIE TEOLOGIE VAN BARTH TEN OPSIGTE VAN DIE PREDIKING}

As daar gedelf word na die grondgedagtes van sy teologie, ontbloot Barth dit self as hy aantoon dat dit vir hom gaan om die kwalitatief oneindige verskil tussen God en mens. Hy erken geen menslike waarheidsnorm nie, alleenlik die openbaring van God. Vanuit die mens is daar geen weg tot God nie (Barth 1952: 16). Hiermee sny hy alle moontlikhede tot ' $n$ analogia entis by die wortel af. Dit is vir hom die grootste dwaasheid en menslike hoogmoed om die openbaring van God te soek in die horisontale vlak van die psigologie, die etiek of die geskiedenis soos die 19de-eeuse teoloë gedoen het.

Die mens beskik nooit oor die openbaring nie, maar hy moet gedurig daarvan vertel word. Hy besit geen vermoë van sy kant om hierdie openbaring te verstaan nie. Alleen God kan oor Homself spreek. Hierdie openbaring word ten nouste verbind met die vleeswording van Christus in so ' $n$ mate dat dit identies is. Alleen Jesus Christus kan openbaring genoem word in die ware sin van die woord. Buite die genade om is van geen openbaring sprake nie, want openbaring en versoening word ook met mekaar geïdentifiseer. Dit gaan in die 
openbaring altyd om met die lewende Woord self in persoonlike aanraking te kom (Barth 1958: 32). Openbaring is altyd 'n daad van God. Die Skrif en prediking is nooit self openbaring nie, maar verwys na en getuig van die openbaring. Vir die prediking is dit ook belangrik om te let op sy beskouing van die drie gestaltes van die Woord, naamlik die vleesgeworde Woord in die openbaring van Jesus Christus; die woord van God in die Bybel as getuienis van die oorspronklike openbaring; die woord van God in die verkondiging van die kerk. Barth lê die sterkste klem daarop dat die woord van God nooit anders verstaan kan word as deur die getuienis van die Heilige Gees, wat die geloofsaanvaarding bring nie. Die mens kan alleen deur die geloof weet dat die Bybel God se woord is. Die Woord in al sy gestaltes is dus nooit iets wat die mens besit en waaroor hy beskik nie, maar' $n$ daad, ' $n$ genadegawe van God wat telkens weer moet geskied (Barth 1952: 276).

Die Bybel is nie an sich God se woord nie, maar die menslike getuienis van God se woord, wat deur die getuienis van die Heilige Gees weer God se woord kan word, in soverre as wat God daardeur tot mense wil spreek. Hy kritiseer juis die kerkvaders daarin dat by hulle: 'de inspiratie niet tot een telkens opnieuw door Gods actuele genadedaad inspireren van de Bijbelwoorden, maar tot een perfectum, een voldongen afgesloten feit, een geïnspireerdheid van de Schrift' (Polman 1955: 123) word. Om Woord te wees is dus geen permanente eienskap van die Bybel nie. Dit moet altyd God se woord word deur die aktualiserende werk van die Heilige Gees. Die handhawing van hierdie beginsel noem Barth die stryd om die soewereiniteit van die woord van God. Die mens is dus nooit meester nie, maar bedienaar van die Woord (Barth 1952: 339).

Volgens die historiese dimensie besien, kom die Bybel voor as ' $n$ gewoon menslike boek waarop die historiese kritiek toegepas kan word; gesien vanuit die geloofsdimensie, maak die Heilige Gees dit tot God se woord in die harte van mense.

Op hierdie fondament rus Barth se beskouing insake die wese, gesag, inhoud en doel van die prediking. Prediking is die derde gestalte van die Woord. Prediking vind plaas binne ' $n$ dialektiese spanning. Die sondige mens kan nooit oor God praat nie. Daarom staan God self in vir wat gespreek word, want net God kan oor God praat. Die krag van die prediking lê nie in die vermoëns van die prediker nie. Geen prediker durf na sy allerbeste preek beweer dat hy die woord van God bedien het nie, want dit hang nie slegs af van deeglike eksegese, of die nakoming van homiletiese reëls nie, maar '... sie ist nähmlich wann und wo es 
Gott gefällt Gottes eigenes Wort auf die Verheiszung dieses göttlichen Wohlgefallens hin wird im gehorsam gewagt' (Barth 1952: 73). Langs die weg van die wonder van die geloof word die Woord realiteit.

Met hierdie standpunt het Barth gepoog om die subjek-objek skema van 'n dualisme tussen historiese en teologiese eksegese, of wetenskaplike en praktiese Skrifuitleg, te oorwin. Met sy Skrifbeskouing wil Barth aandui dat God nie 'n objektiewe fenomeen is wat tot voorwerp van wetenskaplike ondersoek gemaak kan word nie, maar dat die objek van die teologie, oorspronklik subjek was en weer subjek moet word.

In die prediking, die hoor en die verstaan van die Woord in die geloof deur die werk van die Gees, word die Skrif tot Woord Gods: die hermeneutiek is dus die wyse waarop die gaping oorbrug word. Die hermeneutiese metode moet dus die subjek-objek teenstelling oorkom (Pieterse 1979: 24).

Pieterse (1979: 21, 24), beweer tereg dat Barth as 'n oorgangsfiguur die afsluiting van die 'ou' hermeneutiek verteenwoordig en ' $n$ 'nuwe' hermeneutiek inlei, omdat hy deur sy Skrifbeskouing die subjek-objek skema oorkom, en daarmee saam die tweeslagtigheid van 'n 'wetenskaplike' en 'praktiese' Skrifuitleg oorbrug (Lategan 1970: 25). Alhoewel Barth prinsipieel aan die histories-kritiese eksegese sy volle reg gee, het hy hierdie arbeid in eie praktyk van sy eksegese verwaarloos (Lorentzmeier 1968: 30).

Hy soek na ' $n$ alternatief en vind dit in die teologiese eksegese, met dié gevaar dat die historiese uit die gesigsveld verdwyn en dat ewiggeldende dogmatiese waarhede die oorhand verkry. Vir die ontwikkeling van sy hermeneutiese denke laat hy in sy teologiese eksegese die klem val op die verstaan van die Skrif vir die hede. Hy relativeer die absolute objektiwiteit van die ondersoeker ten opsigte van sy stof omdat hy van die bewuste vooronderstelling uitgaan dat die kerk tot op hede in die Bybel God se woord gehoor het en dat die eksegeet in die verwagting leef dat hy ook weer vir sy tyd God se woord sal hoor. In hierdie geval verskaf sy subjektiwiteit toegang tot die saak in die teks. 'Want die objek van die ondersoeker in die Skrif was aanvanklik Subjek en moet weer Subjek word wat die subjek (ondersoeker) aanspreek' (Pieterse 1979: 26).

Met hierdie paar grondlyne van sy teologie het sy denke ten opsigte van die prediking reeds begin uitkristalliseer. Vanuit hierdie breë kontoere, kan sy homiletiek onder die fokus geplaas word. 


\section{BARTH SE VISIE OP DIE HOMILETIEK}

As uitgangspunt vir sy uitsprake oor die homiletiek, wil ons vir die doel van hierdie ondersoek ons beperk tot 'n publikasie wat 'n samevatting is van Barth se homiletiese seminare te Bonn, gedurende 1932 en 1933 (Barth 1966). In hierdie publikasie word in 'n neutedop die siening van Barth weerspieël. 'n Kursoriese oorsig van die publikasie kan die belangrikste bakens aandui.

\section{1 'n Definisie van prediking}

Hy bespreek en kritiseer ter inleiding die definisies van teoloë soos onder andere Schleiermacher, Palmer en Fendt en gaan dan daartoe oor om sy eie definisies te gee. Barth (1966: 30) gee twee moontlike definisies:

1. Die Predigt ist Gottes Wort, gesprochen von ihm selbst unter Inanspruchname des Dienstes der in Freier Rede stattfindenden, Menschen der Gegenwart angehenden Erklärung eines biblischen Textes durch einer in der ihrem Auftrag gehorsamen Kirche dazu Berufenen.

2. Die Predigt ist der der Kirche befohlene Versuch, dem Worte Gottes selbst durch einen dazu Berufenen so zu dienen, dass ein biblischer Text Menschen der Gegenwart als gerade sie angehend in freier Rede erklärt wird als Ankündigung dessen, was sie van Gott selbst zu hören haben.

Uit hierdie definisies word dit weer eens duidelik dat prediking eers moontlik word wanneer die prediker deur God self aangespreek is. Hy beklemtoon die preek as ' $n$ 'vrye rede', waarmee hy impliseer dat die prediker meer sê as wat die teks sê, want dit sluit ook in die teologiese eksegese gerig op die mens hier en nou. Hy verkies ook die woord 'aankondiging' bo 'verkondiging', omdat die prediker alleenlik kan aankondig wat God wil sê en nie die mens wat onder die pretensie verkeer dat hy God se Woord besit en verkondig nie. God self praat en nie die mens nie, daarom kan die mens net aankondig wat God wil sê. Prediking geskied in opdrag van die kerk en daarom sal dit altyd kerklik gebonde wees, via die geroepe en geordende ampsdraer. $\mathrm{Hy}$ maak ook erns daarmee dat die prediking direk gerig is tot die mens van die hede. Met hierdie definisies wil hy wegbreek van die opvattings van Schleiermacher en andere wat die prediking wil begrond in 
die ervaring van die mens. Barth verplaas dit na die kader van die geloof as teologiese werklikheid wat heenwys na die goddelike werklikheid.

\subsection{Kriteria vir die prediking}

Vanuit hierdie definiëring stel Barth (1966: 32-69) 'n negetal kriteria waaraan die prediking moet voldoen. Ons lig 'n paar uit:

\subsubsection{Openbaringsgebondenheid}

Openbaring is 'n geslote sirkel waarvan God die subjek, objek en die bemiddelling tussen beide is. Prediking kan nie die openbaring herhaal en bemiddel nie. Daarom kan die prediking nie ' $n$ bewys van die waarheid van God wees nie, dit kan ook nie 'n lesing oor die Bybel wees nie, maar dit slegs na-sê. Openbaringsmatigheid in die prediking het te doen met die koms en wederkoms van Christus. Dit is nie net bloot die aankondiging van ' $n$ historiese gebeure wat eenmaal plaasgevind het nie, maar van God wat Hom nou nog openbaar. Dit kan nie net prediking wees van wat was en is nie, maar wat moet word, dit moet spreek van hoop en verwagting.

\subsubsection{Kerkgebondenheid}

Die kerk word deur die openbaring gekonstitueer, sy eksistensie bestaan daaruit dat hy die openbaring moet herhaal, daarom val essensie en eksistensie vir die kerk saam. Alleen binne die ruimte van die geroepe gemeente van die Heer kan wettig gepreek word. Binne hierdie ruimte van die gemeente is preek en sakramente ook interafhanklik.

\subsubsection{Belydenisgebondenheid}

Belydenis is verantwoording, antwoord gee op dit wat gehoor is. 'Die Predigt kann nicht anders geschehen als nach der Norm der in der Kirche geltenden Bekenntnisse. Jede Predigt kann nichts anderes sein als ein Akt der Verantwortung gegen den Ruf, eng angeschlossen an das Symbol' (Barth 1966: 49).

\subsubsection{Ampsgebondenheid}

Prediking, gemeente en amp is onlosmaaklik aan mekaar verbonde. As kriteria vir die amp beklemtoon hy die geroepenheid deur God, asook 
die vereistes wat die Skrif stel aan die persoon van die ampsdraer. Die 'bekwaam wees om te onderrig' verbind hy met die teologiese skoling as voorvereiste vir die prediking. In sy prediking kan die prediker hom nie net op die Heilige Gees verlaat nie. Hy moet alles in sy vermoë doen om toe te sien dat hy die woord reg uitdra terwyl hy glo en vertrou dat die Heilige Gees dit moontlikheid en werklikheid sal maak. Vir die gemeente beteken die ampsgebondenheid van die prediker dat hulle iets hoor van die saak van God, deur iemand wat in sy diens staan.

\subsubsection{Die biblisiteit van die preek}

Onder biblisiteit verstaan hy dat die preek Skrifuitleg is, maar dan nie Skrifuitleg wat vasgevang is in 'n eie sistematiek nie. Dit lê veel eerder in ' $n$ houding van openheid by die prediker om vanuit die Skrif die lewende Woord van God te ontvang. Binne hierdie historiese dokument moet hy gelowig soek na die Woord van God vir homself en sy gemeente. Daar moet by die prediker die nederigheid wees om met sy eienskappe en insigte terug te staan voor die Woord. Biblisiteit vereis van die prediker beweeglikheid om homself in hierdie gebeure met die Bybel oor te gee aan die beweging van die Woord self. Waar die Heilige Skrif so heers, sal daar geen 'priesterstand' ontstaan van ampsdraers met 'n geswolle bewussyn oor hulle sending, amp en teologiese kennis nie. In hierdie sin van biblisiteit van die prediking kan die 'priester' nie verseker en selftevrede wees nie. Hierdie biblisiteit bevry die prediking ook van verveligheid, want as die lewende Woord self spreek, is dit telkens 'n nuwe opwindende gebeure.

Die verhouding Ou en Nuwe Testament sien hy in die reglynige skema van profesie en vervulling.

\subsubsection{Oorspronklikheid van die prediking}

Onder die kriterium van die oorspronklikheid, skep hy ruimte vir die eiesoortigheid van elke prediker. $\mathrm{Hy}$ is as mens met sy besondere eienskappe tot hierdie taak geroep.

Auch gerade als Amtsträger gilt es, das zu sein, was man ist. Man hat keinen Charakter anzuziehen und keinen Ornat und hat keine Rolle zu spielen. Du Mensch bist beauftragt, Du, wie Du bist, nicht in Amt, nicht als Pfarrer oder Theologe, nicht in irgendwelcher Geborgenheit oder Deckung, sondern du selber hast einfach diesen 'Auftrag auszuführen' (Barth 1966: 65).

As voorwaarde vir die oorspronklikheid van die prediking, geld ook dat 
die prediker self voor die gemeente moet staan as een wat deur die Woord in beweging gebring is tot oordeel, berou, genade en dankbaarheid. Oorspronklikheid vereis dat die prediker die moed moet openbaar om wat die Woord nou aan hom sê, ook aan ander te sê, as iemand wat tereg die biblisiteit behou, sonder om vas te bly steek by die eksegese, maar waarlik as getuie kan spreek.

\subsubsection{Die gemeenskapsgebondenheid van die prediking}

Prediking is altyd gerig aan die gemeente van God. Christus het vir hierdie mense gesterf en opgestaan; dit is die waarheid wat aan hulle aangekondig moet word. As voorwaardes daarvoor geld dat:

- die prediker sy gemeente moet liefhê;

- die werklike situasie van die gemeente moet ken en in die preek kan verwoord;

- die prediker die takt moet hê om te kan onderskei wat huidiglik in die besondere situasie van die gemeente nie gesê moet word nie;

- die vertrouensverhouding met die gemeente nie uit oormoed en moedswilligheid op die spel geplaas moet word nie;

- die prediker die 'kairós-bewussyn' moet hê om te bepaal wat die situasie waarin ons nou met mekaar verkeer, vereis.

\subsection{Formele vereistes vir preekvoorbereiding}

Barth wy die laaste gedeelte van sy homiletiek aan die vereistes wat geld vir die preekvoorbereiding. Ons wil hier volstaan deur slegs ' $n$ paar van die belangrikste vereistes te noem.

\subsubsection{Tekskeuse}

Hy is versigtig vir te veel vryheid by die keuse van 'n teks omdat die prediker dan makliker van die teks 'n kapstok vir sy eie gedagtes kan maak. Dieselfde gevaar dreig by te kort tekste wat dan maklik los van die wyer verband van die perikoop gebruik kan word. Hy pleit liewer vir voorgeskrewe perikope of reeksprediking. Tog laat hy ruimte daarvoor dat die prediker deur sy eie bestendige omgang met die Skrif deur sekere gedeeltes aangespreek word en daaroor sal preek.

\subsubsection{Eksegese}

Telkens in sy uiteensetting van wat eksegese is, kom die belangrikheid van die samehang van die teks binne sy breër verband (corpus) na vore. 
Sy skerp kritiek teen die absolutering van die histories-kritiese metode figureer prominent. Hy het dit veral teen die 'dogma' van hierdie metode, wat alleenlik rekening hou met die mens en sy wêreld, as die alleen-geldende. Op hierdie 'dogma' as vooronderstelling, kan 'n preek nie gebou word nie. Die 'dogma' wat as vooronderstelling vir die prediker geld, is dat die Woord vlees geword het.

Die formulering van ' $n$ tema of skopus wys hy af, want in die Bybel is net een tema, naamlik God se openbaring in Jesus Christus. Wat in die Bybelteks staan, is nie die openbaring self nie, maar menslike getuienis daarvan. Die prediker kan nie 'n tema preek nie, maar hoogstens sy getuienis aangaande die Openbaring lewer.

Die belangrikheid van die dogmatiek as wegwyser vir die verstaan van die Bybel, beklemtoon hy sonder om verskoning daarvoor te vra. Dit bevry die prediker van willekeur en anker hom in verantwoordelikheid aan die belydenis van die kerk. Hier kom die teologiese eksegese wat hy in sy teologie so sterk bepleit, duidelik na vore.

\subsubsection{Preekmetode}

Die explicatio-applicatio dualisme moet oorwin word deur ' $n$ eenheid, waarin beide tot hulle reg kom in 'n geïntegreerde geheel. Eksegese (explicatio), wat nie van meet af aan uitmond in en weerklank vind by die hoorders nie, het geen bestaansreg nie. Die prediker moet voortdurend verkeer in die dialektiese spanning van teksnabyheid en lewensnabyheid. Die eksegese is weer altyd die korrigering vir die gedagtes van die applicatio.

\subsubsection{Preekvorm}

'n Preek is van begin tot end ' $n$ eenheid, 'n geheel, ' $n$ 'corpus'. 'n Geforseerde indeling van ' $n$ preek in onderafdelings versteur die eenheid van die preek. In die lig hiervan beweer Barth dat 'n preek geen inleiding of slot behoort te hê nie. Hy verwerp ook die inleiding op grond van sy vrees vir die analogia entis wat soek na 'n aanknopingspunt in die mens sodat die Woord ingang kan vind. Die slot van die preek kan weer neig tot die explicatio-applicatio dilemma waar die hele preek explicatio is, terwyl slegs die slot ' $n$ kort applicatio bevat. Die illustratiewe gebruik van voorbeelde in 'n preek, wys hy onder alle omstandighede af. 


\section{BARTH SE PREDIKING IN PRAKTYK}

Teen die dekor van sy teologiese en homiletiese denke kan sy prediking in praktyk gemeet word. Vir die doel daarvan het die keuse geval op twee preekbundels wat preke bevat wat Barth self op 'n gereelde basis gelewer het in die gevangenis van Basel in die jare 1959-1963. Tereg skryf Marsch in 'n voorwoord tot een van die bundels (Barth 1959: 8, 9):

... I suppose that both critics and disciples have often wondered 'How does this theology preach?' ... I think the question would be better put: 'What sort of preaching lies behind this kind of theology?' Here the great theologian can be heard himself. In these sermons he speaks mainly to the inmates of a Swiss prison, for while Professor of Theology at Basel University, Karl Barth has exercised a truly remarkable hidden ministry, visiting and preaching regularly in Basel Prison. I think this congregation would put any man's theology on the test; for it is not easy to know what to say to men and women in prison, nor how to say it.

Binne die omvang van hierdie artikel kan preke nie afsonderlik bespreek word nie. Seleksies en sitate uit beide bundels sal slegs gebruik word ter illustrasie van sekere uitstaande kenmerke van sy prediking.

\subsection{Sy tekskeuse}

In sy tekskeuses blyk dit duidelik dat hy hoofsaaklik deur twee oorwegings gemotiveer is tot die keuse van 'n bepaalde teks. Eerstens is almal tekste wat duidelik gerig is op die situasie en eksistensiële nood van sy hoorders in die gevangenis. Tweedens word dit vanuit die preke self duidelik dat dit in alle gevalle teksgedeeltes is wat homself eksistensieel aangespreek het. Vanuit sy homiletiek word die indruk gewek dat hy hom skerp afgrens teen te veel vryheid in die keuse van 'n teks en kies vir'n perikoopsisteem of reeksprediking. In die praktyk gun hy homself egter die vryheid om vanuit die situasie die teks te kies en dan ook werklik 'n teks waardeur hy self aangespreek is. Dit is ook opvallend dat hy deurgaans slegs kort kernagtige gedeeltes as teks aankondig wat dwarsdeur die preek die eenheid van sy preek verseker. Die kort teks figureer wel in sy wyer verband, maar vir die doel van die prediking word slegs die essensie uitgelig. Die volgende paar tekste vir sy prediking behoort bogenoemde voldoende te illustreer:

Psalm 73: 23 - 'Nevertheless I am continually with thee; thou dost 
hold my right hand' (Barth 1959: 14); Efesiërs 2: 5 - 'By grace have you been saved' (Barth 1959: 35); Lukas 23: 33 - 'They crucified him with the criminals' (Barth 1959: 76); Psalm 50: 15 - 'Call me in the day of trouble, I will deliver you, and you shall praise me' (Barth 1965: 30).

In die praktyk vergun Barth hom dus groter vryhede ten opsigte van sy tekskeuse as wat hy in sy teorie voorstaan. In die praktyk van sy preke lê sy krag en aktualiteit juis daarin dat hy telkens reeds met sy tekskeuse die situasie van sy hoorders in die oog hou. Alhoewel hy in sy homiletiek waarsku teen die gebruik van te kort tekste, omdat dit die gevaar inhou dat die kort teks 'n kapstok word vir die gedagtes van die prediker, getuig sy preke telkens daarvan dat hy een kort kerngedagte uit die teks neem. Juis hierdie kort kerngedagte maak sy preke tot 'n hegte eenheid wat inslag vind.

\subsection{Sy preke as proklamasie van God se heil hier en nou}

In sy Homiletiek is Barth ' $n$ voorstander van die preek as aankondiging in plaas van verkondiging. As 'n mens sy preke deurlees kom jy onder die indruk daarvan dat hy dit baie sterker bedoel as wat die Woord aankondiging aanvanklik sê. Sy preke skep by die hoorder die atmosfeer van 'n kragtige proklamasie en appèl in die Naam van God:

Do you know for whose sake he is hanging there? For our sake because of our sin - sharing our captivity - burdened with our suffering! He nails our life to the cross. This is how God had to deal with us. From this darkness he has saved us. He who is not shattered after hearing this news may not yet have grasped the word of God! By grace you have been saved! (Barth 1959: 38).

Sy preke is 'n proklamasie van die soewereine God nie as 'n historiese gebeure of ' $n$ vae belofte, waaroor gefilosofeer word nie, maar as 'n werklikheid, 'n gebeure, 'n openbaring hier en nou:

I have conquered the world, we hear. Not, I shall do it some day! but: It is finished, it has happened. I have done it. All you need to know is to notice, and to get ready to accept the fact, that you are living in a world conquered by me - and are already men conquered by me (Barth 1965: 107).

Uit hierdie twee voorbeelde van sy preke word dit duidelik dat hy 
daarin slaag om die objek-subjek dualisme te deurbreek omdat hy self as subjek deur die eintlike Subjek aangespreek word en die objek word van die ontmoeting met God. Vanuit hierdie hermeneutiese gebeure word sy prediking die lewende Woord van God wat self tot mense spreek. Die egtheid van sy preke lê juis in die deurleefdheid en worsteling in sy eie geloofslewe.

\subsection{Sy preekstyl}

Van' $n$ teoloog met die statuur van Barth verwag 'n mens dat iets van sy belesenheid, kennis en geleerdheid in sy preke sal deurslaan. Die teendeel is egter waar. Sy preke getuig van 'n eenvoud en duidelikheid wat binne die vermoë van die gewone mens lê. Daar is geen sprake van ingewikkelde teologiese redenasies of akademiese dogmatisering nie, maar van 'n teologie en dogmatiek wat so geïntegreer is met sy geloofslewe dat dit bevry is van enige sweem van akademiese hoogdrawendheid.

Hy handhaaf deurgaans ' $n$ dialogiese styl waar hy in gesprek tree met sy hoorders, hulle vrae en situasie antisipeer en hulle betrokke hou by dit wat gebeur.

But is there such a thing as this? you may well ask me. How are we to imagine it? (Barth 1965: 25). Someone once said to me: 'I need not go to church. I need not read the Bible. I know already what the church teaches and what the Bible says ....' If this were the message at stake, I would most certainly not have come here. My time is too precious and so is yours .... Anybody is at liberty to say this to himself (Barth 1959: 36).

Dit skemer voortdurend in sy preke deur dat hy self ook aangespreek word en self betrokke is by die woordgebeure, somtyds sê hy dit eksplisiet: 'Let me tell you quite frankly: we are all together great sinners. Please understand me: I include myself. I stand ready to confess being the greatest sinner among you all ...' (Barth 1959: 37).

\subsection{Sy explicatio-applicatio verhouding}

Soos hy dit in sy homiletiek bepleit, slaag hy inderdaad in sy prediking daarin om hierdie dualisme te oorwin en tot ' $n$ eenheid saam te snoer. Sy preke is van begin tot einde ' $n$ appliserende eksplikasie. Daar is nêrens in sy preke ' $n$ losstaande eksegetiese gedeelte nie. Sy preke 
getuig daarvan dat sy eksegese alleenlik dien tot sy eie verstaan van die teks, terwyl in die preek die resultate van die eksegese so verwerk is dat dit van meet af aan as kerugma, as lewende Woord van God tot die gemeente gerig word. Dit wil geensins impliseer dat sy eksegetiese arbeid verwaarloos is nie, maar juis dat die resultate daarvan in die preek tot 'n eenheid verwerk is. Sy teologiese eksegese wat hy in sy preek as 'vrye rede' bepleit, vind neerslag in sy prediking. Vanuit sy teologie en dogmatiek beweeg hy in die preek wyer as die teks. Hy verkondig die teks in sy verband tot die geheel van die Openbaring.

\subsection{Sy gemeente- en situasiegerigtheid}

As een van die kriteria vir die prediking het hy die gemeentegebondenheid gestel. Ten onregte word dikwels die kritiek uitgespreek dat Barth die moderne mens in sy situasie nie in ag geneem het nie (Pieterse 1979: 28). Uit sy prediking blyk juis die teendeel. Hy het voortdurend die mens en sy situasie in die oog. Hy verval ook nie in 'n abstrakte filosofering oor sy tyd nie, maar spreek binne die konkrete werklikheid in.

That is one sort of trouble which cannot be covered up, let alone cured: either by Carnival or by the trade Fair or by a jubilee if one is due once again - or by the grandest Olympiad, or by communism, or anti-communism, or by Moral Rearmament as they practise it at Caux on Lake Geneva or by evangelical campaigns ... like the one we recently had in Basel ... (Barth 1965: 32).

Last week a Christmas meditation appeared in the National Zeitung - perhaps one or other or you has read it - in which we were reminded that in the past year man had succeeded in reaching the moon. Nothing could now cancel or alter the fact that the Russians had sent a disinfected capsule up there and now there it is ... (Barth 1965: 14).

Barth is in sy preke mens van sy tyd met sy voete vierkantig in sy wêreld, met 'n openheid en begrip vir die nood van sy tyd.

\subsection{Sy inleiding en slot}

Hy verset hom teen enige vorm van inleiding tot 'n preek wat uitgaan van die standpunt dat daar by die mens 'n aanknopingspunt vir die Woord is, uit vrees vir die analogia entis. Tog maak hy self dikwels in sy 
prediking gebruik van 'n inleiding om sy hoorders van die begin af betrokke te kry by die prediking. 'n Preek oor Psalm 50: 15 begin hy met die volgende inleiding: 'Call me, we read. That reminds me at any rate of someone "calling" me on the telephone that is, and interrupting and disturbing me at my work, or in the middel of a conversation or perhaps when I am just about to listen to some music ...' (Barth 1965: 30).

'n Preek oor Psalm 31: 15 begin hy deur ter inleiding te vertel van 'n vriend van hom wat' $n$ professor is in Frankryk, wat dadelik die hoorder se gedagtes prikkel en vragenderwys betrokke kry by wat hy wil sê. 'n Laaste voorbeeld: 'During the week I read a sentence in the Migros newspaper ... which I expect you know. It was an article entitled "Prisoner's Christmas" ...' (Barth 1965: 68).

Hy gebruik telkens sy inleiding geslaagd en effektief, alhoewel hy self daarteen waarsku in sy homiletiek. Sy preke toon aan dat, as 'n prediker bewus is van die gevare verbonde aan die onverantwoordelike gebruik van ' $n$ inleiding, dit tog met groot vrug vir die prediking geïmplementeer kan word.

Die gebruik van 'n slot wys hy ook af, omdat daaronder dikwels verstaan word ' $n$ los toepassing wat tot 'n stuk eksegese bygevoeg word - hy vermy dit ook in sy preke, omdat sy preke deurgaans toepassing is. Tog gebruik hy die slot van sy preke as 'n klimaks waarin die kerngedagte van die preek vervat is:

And howwould it be, if, tomorrow morning, when we awaken, we were to say, again aloud or softly, exactly the same thing: 'My time is secure in your hands'? ... What a beginning to the year! Yes, what about it? What about that for an ending, what about that for a beginning! Amen (Barth 1965: 47).

\subsection{Die gebruik van illustratiewe materiaal}

Hy spreek hom in sy homiletiek skerp uit teen die gebruik van beelde, voorbeelde en verhale as illustrasies. Tog is sy prediking deurvleg van sulke illustratiewe materiaal en juis dit verhoog die konkreetheid en verstaanbaarheid van sy prediking: '... just as we give a patient an injection - or he gives one to himself. The illness, it is true, wil not be cured, but at least the pain will be alleviated for a while . . .' (Barth 1959: 54). 
Talle soortgelyke voorbeelde kan uit sy preke aangehaal word, waar hy op ' $n$ baie effektiewe wyse gebruik maak van illustratiewe materiaal. Hier is ook 'n diskrepansie tussen sy homiletiese teorie en praktyk.

\section{SLOTOPMERKINGS}

Die omvangryke werk van ' $n$ teoloog soos Karl Barth kan onmoontlik in die bestek van een artikel geëvalueer word. Dit was hoogstens ' $n$ poging om enkele flitse te gee van Karl Barth as homileet. 'n Paar dinge het ooglopend na vore gekom.

$5.1 \mathrm{Om}$ ' $\mathrm{n}$ teorie en metode vir die prediking te ontwerp, is een saak, om dit altyd konsekwent in die praktyk toe te pas, is 'n ander saak. Hierdie tweeslagtigheid het ook by Barth deurgeskemer. Miskien kry ' $n$ mens beter begrip vir hierdie diskrepansie as ' $n$ mens dit sien in die lig van die feit dat elke verantwoordelike teoloog en leermeester sy studente in skerp taal moet wys op gevare en dwalings, maar tegelyk as verantwoordelike prediker dit waarteen hy waarsku, in sy prediking kan gebruik, juis omdat hy weet om die slaggate te vermy.

5.2 'n Allesoorheersende indruk wat 'n mens van Barth as homileet bybly, is dat sy pediking nie die blote akademies-eksegetiese dissektering van ' $n$ historiese teks is nie - sy prediking is ' $n$ gebeure, 'n ontmoeting met die lewende Woord van God hier en nou. Hy openbaar die homiletiese moed en onderneem die waagstuk om die heil van God vir die mens van sy tyd te proklameer. Miskien is dit juis die groot les wat ons in ons tyd van hom kan leer, om ons nie so besig te hou met die historiese teks, die outeur, die selfstandige corpi, dat die lewende God nie meer in die prediking werklik aan die woord kom nie!

5.3 Die eenvoud van styl waarmee hierdie groot teoloog die Woord bedien, behoort ons as 'vermeende' teoloë en akademici tot eenvoud terug te dwing.

5.4 Die bewoënheid, piëteit en liefde vir die kudde van die Heer tot wie hy preek, bevestig sy roeping as bedienaar van die Woord.

Ter afsluiting dring een gedagte telkens na vore. In Barth se teologie gaan dit nie vir hom om teologiese gimnastiek of akademiese interesse nie, maar om die dodelik erns van sy sondaarwees voor God en die blye 
dankbaarheid oor sy verlossing in Jesus Christus. Daarom is sy preke eg, oortuigend en aangrypend.

\section{Literatuurverwysings}

BARTH, K 1952. Kirchliche Dogmatik. 1/1 Zürich: Zollikon. BARTH, K 1958. Kirchliche Dogmatik. 1/2 Zürich: Zollikon. BARTH, K 1959. Deliverance to the captives. London: SCM.

BARTH, K 1965. Call for God. London: SCM.

BARTH, K 1966. Homiletik: Wesen und Vorbereitung der Predigt. Zürich: EVZ.

BARTH, K 1970. The humanity of God. 9th ed. Richmond: UP.

BERKOUWER, G 1937. Karl Barth. Kampen: Kok.

BERKOUWER, G 1954. Triomf der genade in de theologie van Karl Barth. Kampen: Kok.

KOTZE, GJ 1963. Hedendaagse Skrifprediking: 'n Ondersoek na die mistastinge in die prediking van die nuwere tyd. Potchefstroom: Pro Rege.

LATEGAN, BC 1970. Hermeneutiek en geskiedenis. Neotestamentica 4, 19-40.

LORENTZMEIER, T 1968. Exegese und Hermeneutik. Hamburg.

PIETERSE, HJC 1979. Skrifverstaan en prediking. Pretoria: NG Kerkboekhandel.

POLMAN, ADR 1955. De Theologie van Augustinus: Het Woord Gods bij Augustinus. Kampen: Kok.

VAN NIEKERK, AA 1984. Analogie fidei teenoor analogia entis: Karl Barth en die verstaanbaarheid van ons spreke oor God. NGTT 25, 410-424.

VAN NIFTRIJK, GC 1949. Een beroerder Israels. Nijkerk: Callenbach. 